\title{
Activities of lipogenic enzymes in subcutaneous adipose tissue from normal and double-muscled Belgian-Blue calves
}

\author{
P Bas 1, JF Hocquette 2, D Bauchart 2, Y Geay 2, \\ IINRA-INAPG, Laboratoire Nutrition et Alimentation, 75005 Paris ; 2/NRA, Laboratoire Croissance ef \\ Métabolismes des Herbivores, 63122 St-Genès-Champanelle, France
}

Compared to normal animals $(N)$, doublemuscled (DM) cattle exhibit muscular hypertrophy and lower fat deposition (especially in subcutaneous adipose tissue (SCAT)) which suggests differences in nutrient partitioning between muscles and adipose tissues (AT). Therefore, the objective of the present study was to relate the differences in fat deposition in SCAT between $\mathrm{N}$ and DM calves to possible differences in activities or lipogenic enzymes.

Ten Belgian-Blue male calves, $5 \mathrm{~N}$ and $5 \mathrm{DM}$, were weaned at $122 \pm 10$ days of age. They were then kept tethered indoors and feed individually nearly ad lib a diet composed of $50 \%$ grass hay in the long form and $50 \%$ pelleted concentrate feed. The concentrate consisted of maize, soybean meal, dehydrated lucerne, sugar cane molasses, urea and mineral compound $(57.5,24.0,12.0,2.0,2.5$ and $2.0 \%$ in wet matter respectively). Animals were slaughtered at the same mean age (307 days), $12 \mathrm{~h}$ after their last meal. Samples of SCAT were taken near the rump at the time of slaughter, frozen in liquid nitrogen and kept at $-80^{\circ} \mathrm{C}$ until determinations of DNA and lipid contents and enzyme activities as follows : glucose-6-phosphate dehydrogenase (G6PDH), malate dehydrogenase (MD) and fatty acid synthetase (FAS) activities were determined spectrophotometrically at $37^{\circ} \mathrm{C}$ (Bas et al, 1992, J Anim Sci, 70, 3857-3866 ; Halestrup and Denton, 1973, Biochem J, 132, 509-517), lipoprotein lipase activity (LPL) was measured at $25^{\circ} \mathrm{C}$ with $\left({ }^{3} \mathrm{H}\right)$ triolein as substrate (Peterson et al, 1985, Biochim Biophys Acta, 837, 262-270).

From 4 to 10 months of age, the average feed intake, the daily gain and the feed efficiency were similar for both groups. However, empty body weight and carcass weight were higher in DM calves than in $\mathrm{N}$ calves $(+9.3$ and $+21.7 \%$ respectively, $\mathrm{P}<0.01)$. In contrast, $\mathrm{DM}$ calves exhibited a lower fat deposition in the carcass (4.4 vs $10.6 \%, P<0.01$ ). The proportion of
SCAT in total AT of the carcass was lower in DM calves than in $N$ calves (5.6 vs $14.5 \%$, $\mathrm{P}<0.01)$. However, the ratio of SCAT weight to cacass weight was highly correlated with the proportion of total AT in the carcass ( $r=0.93$, $n=10, P<0.01$ ), which suggests that the metabolic activity of SCAT was representative of the metabolism of total AT in the carcass.

DNA content was higher (1066 vs $696 \mu \mathrm{g} / \mathrm{g}$ fresh tissue, $P<0.01)$ and lipid content was lower (372 vs $964 \mathrm{mg} / \mathrm{mg}$ DNA, $P<0.01)$ in SCAT from DM calves than from $N$ calves which suggests that adipocytes of SCAT were smaller in DM calves. Consequently, all the results were expressed per mg DNA to take into account the variation in cell size of SCAT between animals. G6PDH and MD activities were lower in SCAT from DM calves (593 vs $2131 \mathrm{nmol} / \mathrm{min} / \mathrm{mg}$ DNA, $P<0.001$ and 30 vs 70 $\mathrm{nmol} / \mathrm{min} / \mathrm{mg}$ DNA, $\mathrm{P}<0.01$, respectively). In spite of large interindividual variations, LPL activity tended also to be lower in SCAT from DM calves than from $N$ calves (771 vs 1756 $\mathrm{mU} / \mathrm{mg}$ DNA, $\mathrm{P}=0.18$ ). In contrast, FAS activity was not significantly different between the two groups.

In the two groups, G6PDH activity was highly correlated with MD activity $(r=0.94, P<0.01)$. In the same way, G6PDH and MD activities were positively correlated with lipid content (per mg DNA) in SCAT ( $r=0.84$ and 0.79 , respectively, $P<0.01$ ) and with the proportion of total AT in the carcass $(r=0.96$ and 0.95 , respectively, $P<0.01)$. These results suggest that G6PDH and DM are important enzymes for fat deposition, at least in SCAT.

In conclusion, our results show a lower activity of some lipogenic enzymes (G6PDH, MD and LPL) in SCAT from DM calves. This may be related to the lower fat deposition in DM calves, especially in SCAT. Moreover, these data suggest that the low metabolic activity of adipose tissues in DM calves may modify energy-yielding substrate partitioning between muscles and AT and favour energy utilization by muscles. 